\title{
CONTRIBUTION OF CREATIVE AND CULTURAL INDUSTRIES TO DEVELOPMENT OF CULTURAL TOURISM IN SERBIA
}

\author{
Ivana Božić Miljković, \\ Nikica Radović, \\ Marija Nešić
}

Singidunum University, Belgrade, Serbia
Correspondence: Ivana Božić Miljković

e-mail:

ibozic@singidunum.ac.rs

\begin{abstract}
:
Over the last couple of years, tourism in Serbia has been recognized as a propulsive economic industry which contributes to faster economic development and a better balance of payments position of the country. Similarly to other industries, the issue of competitiveness is present here as well. Due to the heterogeneous nature of the tourism industry, this problem is multidimensional and far more complex than in other industries. Consequently, the mechanisms which can be employed to improve the competitiveness in this area are more complex. Among them, the creative economy is becoming increasingly important, and, within its scope, the creative industries as a set of activities which are a product of talent and creative potential of individuals and their individual or joint engagement.

The aim of this paper is to draw attention to the growing role of the creative economy and creative and cultural industries in creating an authentic Serbian tourism product - cultural tourism, whose quality can be recognized on the European and world market and which, as such, can contribute to faster economic development.
\end{abstract}

Keywords:

cultural tourism, creative economy, cultural industries, competitiveness

\section{INTRODUCTION}

The tourism industry of the Republic of Serbia operates in the coordinates of a very complex and layered market system. It is part of the tourism market of the Balkan countries in transition and is, therefore, burdened with economic and political legacy of the recent past. Geographically speaking, it is also part of a broad European market, where the EU countries are highly positioned. Promotion of the EU tourism market in the world and demand for the world's tourist destinations, generated by high living standards of the population, are part of its international political and economic relations with the world, which reflects favorably on the competitiveness of its tourism industry. Finally, the tourism industry of the Republic of Serbia is part of the global market of tourism services, well known for intense competition and renowned 'players' in the field of tourism, who ensure good competitive positions and conditions for the increase in competitiveness by offering more and more sophisticated services. As for the competitiveness of the tourism industry of the Republic of Serbia, it is very low, 
both in European and global terms. There is potential for its improvement, and it is conditioned by material resources and contribution of individuals and groups, i.e. individual and collaborative ideas and creativity, to the creation of an authentic tourist product.

A rich historical and cultural heritage and natural resources of the Republic of Serbia provide a quality basis for the development of a myriad of tourist products comprised of tradition, culture, religion, art, mountain clear air, thermal springs and unspoiled nature. The creative economy, i.e. the tools of the creative and cultural industries, whose implementation can, with small investment, produce significant results, provides special support to the development of these products and their promotion on the European and world market.

\section{CONCEPT AND IMPORTANCE OF CREATIVE ECONOMY AND CREATIVE CULTURAL INDUSTRIES}

The creative economy is a concept stemming from the interface and interplay between human creativity and ideas and intellectual property, knowledge and technology (UNCTAD, 2004). Essentially the creative economy consists of economic activities based on knowledge, skills and talents. The creative industries in synergy with the culture of a particular region form an integral part of the creative economy. At the heart of these industries is the intellectual capital of an individual, i.e. their ability to place their own creativity, skills and talents - expressed through cultural segments: music, dance, architecture, design, visual arts, theatre and film art - at the disposal of the economic development of their country. The economic significance of the creative industries lies in the fact that individuals or groups of people who possess the aforementioned skills and talents have the knowledge and ability to economically valorize them in the marketplace, to increase the employment by creating jobs and to continuously contribute to the growth of their country's wealth by improving their skills and talents and their activities. The importance of creativity, i.e. culture and various forms of art, in economic development was recognized even in the second half of the $20^{\text {th }}$ century, and today - in the era of globalization, high respect for diversity, the promotion of individualism and authenticity - is gaining even more in importance. Creativity and art are fluid categories, underlied by uniqueness, freedom and individuality, and therefore, it is difficult to define them precisely and comprehensively. Recognizing the fact that the creative and artistic potential of the people of a particular country shape its culture and change it over the centuries, (UNESCO 1948, 1995, 2001, 2005, 2006) integrates the cultural industries into the development agenda of each country defining them as those industries that 'produce tangible and intangible artistic and creative output and have a potential for wealth creation and income generation through the exploitation of cultural assets and production of knowledge-based goods and services (both traditional and contemporary). Common to all cultural industries is the use of creativity and knowledge in the field of cultural and intellectual property in the production of goods and services of social and cultural significance.' (UNESCO, 2010).

Institutional frameworks for human rights protection in the field of the creation and consumption of cultural contents and in the field of the cultural industries development consist of various international documents and interstate agreements. At their core lies the concept of culture as an important segment of the development of human society, as well as the relation of culture to the development and its impact on other segments of that development. Some of the most important international documents in this area are: the Universal Declaration of Human Rights adopted by UNESCO in 1948, the World Cultural Commission report 'Our Creative Diversity' adopted by UNESCO in 1995, the UNESCO Universal Declaration of Cultural Diversity from 2001, the UNESCO Convention on the Protection and Promotion of Cultural Expressions from 2005, the UNCTAD Declaration on Cultural Industries and Development adopted in 2004, the UN Resolution on Culture and Development adopted in 2010 and others.

The economic significance of cultural industries came to the fore at the beginning of the second decade of this century when the world was recovering from the major economic crisis that had erupted in the US in 2008. The National Governors Association's 2012 report 'New Engines of Growth: Five Roles for Art, Culture and Design', suggests how art, culture and design can accelerate the economic recovery of the American nation. Among these recommendations, the new tasks of the cultural industries are: creating dynamic industrial clusters, helping mature industries to improve their competitiveness, promoting innovation whenever possible, fostering community revitalization and awakening creative potential in the working age population (Sparks et al., 2012). 
Some of these recommendations have universal application and as such can be approved of and realized in those countries and parts of the world that, for many years, have been facing various problems that hinder their economic development and make them lag behind the economically developed countries. The study 'The Economy of Culture in Europe' of October 2006, done for the needs of the European Commission, elaborates on a more comprehensive impact of the cultural industries on economic development, referring to it as part of a wider social development. The cultural industries in this study aim to mitigate the economic and social differences resulting from the new post-Cold War polarization of the world: the differences between the economically developed and underdeveloped countries, but also a wide range of differences among communities, groups and individuals, where even in the $21^{\text {st }}$ century there are marginal groups based on ethnic, religious, racial and other characteristics. The authors of this study recognize culture as a very powerful means for alleviating differences and in this regard make the following recommendations:

1. Encouraging grassroots activities aimed at achieving social and socio-economic empowerment (cultural projects, cultural associations, amateur theater and dance groups, festivals, etc.)

2. Realization of projects initiated by institutions and aimed at strengthening the local economic development.

3. Realization of projects that promote territorial cohesion, tolerance and understanding, which can contribute to the development of some forms of economic cooperation.

4. Developing talents and skills that are applicable in many different areas of economic activity and that contribute to the reduction of the unemployment rate, which has a double effect: primarily on the increase in the standard of living of individuals and, then, in the strengthening of their self-esteem (The Economy of Culture in Europe, 2006, p. 9).

Serbia is among the countries which belong to the European, or narrowly, Balkan cultural milieu. As a country in transition, it is burdened with numerous economic problems, some of which are a product of historical and political events from the end of the $20^{\text {th }}$ century, and some are conditioned by large and complex demands of the transition process. Today, Serbia is a country whose economic development is conditioned by the inflow of foreign capital, and the pace and quality of the development are determined by the volume and schedule of the inflow. It is the service sector that dominates the structure of the Serbian economy. From the beginning of this century to the present day, a large part of total foreign investment has been placed in this sector. When it comes to the structure of the investment beneficiaries, the most prominent sector is the sector of finance and insurance, telecommunications and real estate. Besides these sectors, in recent years more and more investments have been directed towards the tourism sector: tourism has been recognized as a highly propulsive economic industry, which, in addition to successfully improving the image of Serbia in the world, represents a very important Serbian export product. The development of the tourism industry is in all parts related to the development of the creative and cultural industries. These industries direct and help the development of tourism, making Serbia's tourist offer more diversified and richer. The creative and cultural industries are a reliable tool in strengthening the national tourism identity of Serbia, which is based on cultural and historical heritage, natural beauty and gastronomic specialties. These industries emphasize, first and foremost, the authenticity which, by definition, is a symbol and result of the social construction of tourism potentials (Vukonić and Čavlek, 2001). In addition, authenticity is often complementary to all those elements that determine the level of quality of a particular tourist service and as such plays an important role in the competitiveness of the tourism industry.

\section{DETERMINANTS OF COMPETITIVENESS IN THE TOURISM INDUSTRY OF THE REPUBLIC OF SERBIA}

According to the most general definition, competitiveness represents the ability of the national economy to produce, with the maximum engagement of the available resources, and export its products to the world market, thus providing the population with a higher standard of living and better living conditions. In economics, competitiveness is mainly related to the national economy and determines the position of a country in international economic relations; however, the generators of competitiveness, or the place where it originates, are economic subjects, sectors, regions and supranational entities (Krugman, 1997, p. 6). From this point of 
view, national competitiveness represents the sublimated values of individual business performance of the listed microeconomic entities, i.e. the sum result of their individual competitiveness. Achieving a certain level of competitiveness, and then maintaining its constant improvement, is a big and complex challenge for all sectors of the economy. When it comes to the tourism industry, this complexity is especially pronounced and conditioned by the very nature of tourism, which, by definition, is an activity determined by social relations, political stability, economic development, cultural heritage and development potentials. The specificity of the tourism industry is evident even by the place where it is created and where its competitiveness is measured. The consideration of the issue of a tourist destination competitiveness is based on the view that the experience which a tourist has in a tourist destination is a fundamental product in tourism (Popesku, 2007, p. 22). Consequently, a tourist destination is in the focus of competitiveness in tourism. The model for the assessment and measurement of competitiveness is hence complex and multidimensional. Determinants of the measurement of competitiveness are primarily defined by the choice of variables that will be analyzed, and then by the geographical base that more closely determines the tourist potential, i.e. the feature of a tourist destination (sea, mountains, spas, cultural and historical sites, etc.).

The literature offers different perspectives on the determinants of the measurement of competitiveness in the tourism industry. The core of their differences usually lies in the perception of tourist destinations, i.e. the differences in the perception of the elements that tourist destinations are comprised of. For example, according to some authors, the resources of tourist destinations can be either natural (beaches, mountains) or cultural (museums, festivals, local traditions) (Melian-Gonzales and Garcia-Falcon, 2003). Others argue that there are two basic factors, and within them subfactors, to be involved in the measurement of competitiveness: primary (climate, ecology, culture, architecture, etc.) and specific (hotels, transport means, entertainment opportunities, etc.) (Kozak and Rimmington, 1999). In the opinion of some authors, the determinants of tourist destination competitiveness are: prices, economic openness of a country and the level of the realized technological development (Gooroochurn and Sugiyarto, 2005). A general and comprehensive list of the determinants of tourist destination competitiveness that includes price and specific non-taxable factors is given in the Table 1 .

Table 1. A list of core, supplementary and future development indicators of tourism industry

\begin{tabular}{|c|c|}
\hline \multirow{4}{*}{ Tourism performance and impact on the economy } & Share of tourism in GDP \\
\hline & Revenue from tourism \\
\hline & Overnights in all types of accommodation \\
\hline & Exports of tourism services \\
\hline \multirow{3}{*}{$\begin{array}{l}\text { Ability of a destination to provide quality and competitive } \\
\text { tourism services }\end{array}$} & Labour productivity in tourism \\
\hline & Purchasing power parity and prices in tourism \\
\hline & Country entry visa requirements \\
\hline \multirow{3}{*}{ Destination attractiveness } & Natural resources and biodiversity \\
\hline & Cultural and creative resources \\
\hline & Visitor satisfaction \\
\hline Economic policy and economic opportunities & Tourism action plan \\
\hline
\end{tabular}

Source: Dupeyras, A. and MacCallum, N. (2013). Indicators for Measuring Competitiveness in Tourism. A Guidance Document. OECD Tourism Papers, 2013/02. OECD Publishing. http://dx.doi.org/10.1787/5k47t9q2t923-en (accessed: 07/08/2018)

In Serbia, a new concept of development favored the service sector and made it dominant in the structure of the economy. Within this sector, tourist services hold a significant place. Given the specificity of the tourism industry itself, and also the characteristics of Serbia as a tourist destination - its historical heritage, the image it enjoys in the world, political and macroeconomic stability, social relations, the current relation to the development of the tourism industry and future plans in this direction, it is necessary to continuously monitor 
competitiveness and make steady efforts towards its improvement. The significance of the tourism industry in Serbia can best be presented through the data on the growth of tourism's share in GDP in the last ten years. It is obvious that in the period from 2007 to 2017, the share of tourism in GDP of Serbia increased by $1.7 \%$. The increase of tourism's contribution to the GDP is determined by significant investments in the improvement and modernization of domestic accommodation and catering facilities, continual enrichment of the tourist offer, as well as the improvement of Serbia's reputation and image in Europe and the world

In European and world context, Serbia is nowadays recognized as a country of particularly rich cultural and historical heritage that is in the service of developing its tourist offer, a country of great and world-renowned music, film and dance festivals, a country of authentic gastronomic specialties that are increasingly conquering the world market, and as a very popular destination when it comes to winter and summer mountain tourism. Also, ethnic tourism is becoming more common in Serbia, as a modern and increasingly popular type of tourism, along with adventurous, religious and educational tourism (mushroom hunting, medicinal herbs picking, etc.) as new forms of tourism that arouse the growing interest of local and international tourists. Serbia is a country in transition and as such has modest opportunities for large investments in tourism development. On the other hand, there is intense competition in the surrounding countries, in terms of not only tourist offer, but also attracting foreign investments into the development of tourism economy. In order for tourism development to continue its upward trajectory, the creative industries are expected to take greater part in and offer significant support to the improvement and promotion of the existing tourist offer and the realization of untapped potentials which can be brought into service of tourism development and which can produce desired effects in no time. The creative economy, and creative and cultural industries, can make an extraordinary contribution not only to the promotion and development of authentic features and cultural heritage of Serbia, but also to shaping some kind of folk creativity (music, dance, culinary specialties, folk arts) into a certain artistic direction and creating conditions for some of these tourist values to be formally recognized as part of this geographical area (Božić Miljković, 2016, p. 194).

\section{SYNERGY OF CREATIVE ECONOMY AND CULTURAL TOURISM}

The diversity of the tourist offer of Serbia, the richness of anthropogenic tourist resources interwoven with elements of the creative and cultural industries are some of the segments for the improvement of economic trends in Serbia and its competitiveness, both from the perspective of a tourist destination and economic results as a whole. The Tourism Development Strategy of the Republic of Serbia for the period from 2016 to 2025 identifies priority tourism products for tourism development: city tours, events (cultural/sports), mountain tourism, spa\&wellness, themed tours, rural tourism, nautical tourism, MICE tourism, cultural heritage, special interests, transit tourism.

The synergy of cultural and creative industries appeared at the end of the $20^{\text {th }}$ century when parts of the cultural industries, such as multimedia, software creation, audio and visual industry, architecture and design, went beyond traditional boundaries (Radović and Čigoja Piper, 2016). Creative tourism is considered to be a new 'generation' (type) of tourism oriented towards the intersection of segments of the cultural and creative industries: cultural tours, museum visits, music, film, enogastronomic and traditional events and the like, and according to UNESCO it is defined as an 'engaged and authentic experience, with participative learning in the arts, heritage or special character of a place [..., which] provides a connection with those who reside in this place and create this living culture (www.ec.europa.eu).

Creative sectors contribute to the improvement and growth of economy, especially when it comes to transition and developing countries, which are in a position to diversify their economies in order to consolidate and improve their status. The contribution of the global creative economy is reflected in the revenues of US $\$ 2,250$ billion and 29.5 million employees worldwide (Ernst\&Young, 2015). According to the CIA data for 2017, the share of economic sectors in GDP of Serbia is as follows: $9.8 \%$ agriculture, $41.46 \%$ industry and $49.1 \%$ services (www.cia.gov). Namely, the sector of creative industries in Serbia is included in the service sectors, along with the financial sector, the tourism sector, the trade sector, the transport sector, etc. According to the World Bank report, total revenues of the creative industries in Serbia account for 13.5\% of GDP, and employ more than 100,000 people, aged 25 to 44 . 
The Government of the Republic of Serbia recognized the results and potentials of the creative economy and, as a response, in March 2018, they established the Creative Industries Council. The key role of the Council will be promoting the innovation and creativity in this field of business with the aim of building a new image of Serbia. Also, one of the roles of the Council will be to encourage a cross-sectoral dialogue and cooperation within creative industries, as well as their interaction with other sectors of the economy (www.srbija.gov.rs). The Sector for Contemporary Artistic Production and Creative Industries at the Ministry of Culture and Information of the Republic of Serbia is committedly engaged in activities related to literature and publishing, contemporary visual arts and multimedia, theater and dance arts, music and discography, cinematography, amateur arts, supervision of the professional work of cultural industries in the field of contemporary arts, as well as the creative industries, proposing measures for their improvement. Futhermore, the Ministry has devised the Culture Development Strategy of the Republic of Serbia for the period from 2017 to 2027, which defines the cooperation in the interdisciplinary field of culture and tourism, along with the measures to be taken in order to increase the share of cultural tourism in the offer of Serbia as a tourist destination. Some of the measures are: 'encouraging the development of diverse, high-quality, attractive and innovative cultural and tourism products, programs and content, appealing to local and international tourists, better use of the potential of cultural heritage in the development of audience, through innovations in presenting its meaning and significance, the development of sustainable development projects through the cooperation of tourist organizations with cultural insitutions, the application of competitive strategy (authenticity, high quality, lower prices in comparison to the countries in the region), as well as directing marketing activities to a specialized cultural tourism market, and encouraging and supporting projects that connect the creative industries and tourism (e.g. souvenir development, site design, etc.)' (www.kultura.gov.rs)

The creative industries represent a variety of activities based on skills, talents and creativity, including: film, video and photography, design, publishing, architecture, communication technologies, software and computer games, toys, music, visual and performing arts, crafts, advertising, radio, television, fashion, and, according to the UNESCO report, cultural tourism as well. From a strategic point of view, it would be desirable to look at the synergy of the sectors of the creative industries and tourism, which, with the many potentials we have in Serbia, create great development power. Cultural tourism is a specific product, such that it is possible to implement it as an integral element through other forms of the priority tourism products of Serbia: city tours, rural tourism, MICE tourism, themed tours and events. During the realization of some of the priority tourism products, material or non-material cultural resources emerge in the form of sightseeing tours and visits of art facilities (museums, galleries, theaters, cinemas), cultural monuments (monasteries, famous places), organization of events (music, film, enogastronomic) or familiarizing with ethnological resources (traditional crafts, customs, games, poems) and the like. The creative industries in Serbia operate in the field of the film industry development through domestic production projects, but also through potential projects with foreign investors and partners. The possibility of organizing visits to the sites where some of the cult films and series (so-called exteriors) were shot represents an attractive product in synergy with tourism. The synergy of creativity, culture and tourism in Serbia is achieved through the most popular attractions, events/festivals that are recorded in the world film and music events calendar.

One of the notable international cultural events in Serbia is 'Belgrade Book Fair'. The $62^{\text {nd }}$ International Book Fair, which was held in 2017, was attended by 519 book publishers, with 514 co-publishers and related companies (distributors, bookstores). This event is an important interface for book lovers, and in 2017 there were 187,457 visitors and about 1,200 accredited journalists. The revenue which this event generates comes from exhibiting space fees, ticket sales, accreditation fees for journalists, book sales, accommodation and food fees of exhibitors, as well as any additional expenditures that exhibitors have.

Attractive activities for foreign visitors are Danube cruises, visits to fortifications, as well as prehistoric and Roman archaeological sites, important for our cultural heritage (Vinča, Lepenski Vir, Viminacium, Romuliana, etc.) A special segment in the range of cultural tourism are themed tours, which are based on a defined topic that represents the idea of organizing a stay at one destination, as well as connecting two and more destinations. Important themed tours in Serbia are the Roads of the Roman Emperors, Transromanica, Tesla Roads, Wine Routes, Monastery Tours and the like. What can also be interesting is devising clusters with a specific topic, as a guiding theme, where the segments of the creative industries and tourist activities are intertwined by presenting localities and narratives that are related to the theme and that attract a certain group of tourists. 
A good example of the synergy between the creative economy and tourism, with positive results achieved from the realization of the activities, are the so-called creative cities and regions, the leaders of which in Serbia are currently Novi Sad, with the project of the music festival EXIT, and Pirot, the first municipality in Serbia that has an Agenda for creative industries development. The Agenda enables the linking of cultural heritage and economic potential with the aim of promoting creative entrepreneurship, which is based on the specific and genuine intangible heritage of this region - traditional crafts (pottery, carpeting, weaving, ethnogastronomy). The Agenda's implementation ensures the protection of the local cultural heritage, the promotion and sale of products made by the creative entrepreneurs of Pirot, the employment of the local population, and the development of rural and cultural tourism, which are the priority tourism products of this tourist destination.

In 2018, the $18^{\text {th }}$ music festival EXIT, a unique historical and cultural resource, was held on the Petrovaradin fortress, Novi Sad. More than 200,000 people from over 70 countries around the world visited the festival. Once again it confirmed its title as the Best European Music Festival. According to the data of the EXIT organizer, 'TIM Center' was hired to carry out research and the obtained results confirmed the festival's great contribution to the region's economy, as it is organized not only in Novi Sad/Serbia, but also in Croatia, Montenegro and Romania. In 2017 EXIT brought Serbia an inflow of EUR14.4 million, and since the festival's founding in 2000, the inflow exceeds 150 million euros. Also the research has shown that non-European tourists (6.3\%) spend the most, i.e. over 600 euros per person, Western Europe tourists (21.6\%) spend 532 euros, and domestic visitors on average 312 euros (www.exitfest.org). According to Jovičić and Hristić (2006) the creative industries influence the development of local self-governments and the region, and EXIT, as an interesting example, contributes to the promotion of Novi Sad and Serbia as a destination breaking down the stereotypes formed about Serbia, contributes to the development of economic, tourism and cultural potentials of Novi Sad and its surroundings, resulting in an increase in direct and indirect cash flows into the local self-government/economy, the employment of the local population, and the development of the cultural identity. Apart from this already 'mature' music festival, other music festivals are being organized throughout Serbia in 2018, and they represent the leaders in the region when it comes to other types of sound $-58^{\text {th }}$ Dragačevski Trumpet Festival in Guča, $24^{\text {th }}$ International Jazz Festival Nisville in Niš, $16^{\text {th }}$ Belgrade Beer Fest, $52^{\text {nd }}$ Gitarijada in Zaječar, and the like. At the beginning of 2018, the $11^{\text {th }}$ International Film Festival Kustendorf was held in Mokra Gora. This year Kustendorf, as one of the most important and most original cultural events, where eminent people from the world film industry gather, was financially supported by the Ministry of Culture and Information with the aim of promoting culture and creative film industry.

A good example of this kind of activity in the field of cultural and creative tourism is a manifestation called 'Night of Museums'. 'Night of Museums' represents a unique cultural spectacle of a global character, bearing in mind that it is organized in more than 120 cities around the world. Initially launched as a private initiative, the event has been organized in Belgrade since 2005. The first 'Night of Museums' was held in 5 Belgrade museums and galleries, and it managed to animate more than 4.000 visitors, while for the next 14 years this number rose to incredible 500,000 visitors and 47 places in 2018, at more than 226 locations, with more than 500 different events in museums, galleries, temples of art and culture in Serbia.

Tourists visiting such manifestations and staying at the destination allocate their budget among tickets, accommodation, food, drinks, souvenirs that are related thematically to the event itself (hats, T-shirts, bags, etc.) and/or the destination they are staying at (e.g. magnets, maps, monographs of Belgrade, Novi Sad and Serbia). A certain number of tourists staying in Serbia use the opportunity to visit some places, so they allocate budget to the means of transport (bus, taxi, rent-a-car) in order to visit museums, galleries, monasteries, archaeological sites, ethno facilities and the like, which also contributes to the revenues generated from tourism services. Serbia also generates revenues from collecting tourist taxes from visitors; however, evasion occurs due to lack of records and insight into the number of visitors who use alternative types of accommodation facilities (rent-a-flat concepts, hostels, etc.), whose owners have not complied yet with legal regulations. According to the Statistical Office of the Republic of Serbia, in 2017 a total of 3,085,866 tourists visited Serbia, which is 12\% more than in 2016 (www.rzs.gov.rs). The number of domestic visitors is 1,588,693 (+8\%) or 51\% of the total number of guests, and of foreign visitors 1,497,173 (+17\%), or $49 \%$ of the total number of guests. According to the Ministry's data in 2017, foreign exchange inflows from tourism amounted to EUR1.180 million and increased by $13.4 \%$ compared to 2016 (www.mtt.gov.rs). 
The creative and cultural industries contribute to the creation of new jobs, the increase in operating revenues, as well as in public revenues from taxes and fees, and thus to the increase of budget and overall strengthening of country's economy. Bearing in mind the positive effect, from the economic point of view, it is equally important to point out the promotion of culture, as one of the 'leitmotifs' of this industry, which contributes to the positive branding of a destination and affects its attractiveness and authenticity, thus contributing to the development of tourism and increasing the demand for a destination in the global tourism market. According to the KEA study 'Economy of Culture in Europe' business activities that are closely related to culture represent $15 \%$ of all jobs in the tourism sector. Creative economy contributes to the development of tourism and in this sense economic diversification and specialization should be initiated in order to affect the attractiveness of Serbia as a destination. Creative tourism rests on the interaction of a tourist with a destination, the way of life and culture, with the aim of developing an individual's educational, emotional and social awareness of the visited place. Nevertheless, according to UNESCO's research (www.unesco.org), in order to develop the creative industries and creative tourism, there are private and public sector responsibilities to be taken. Namely, the public sector should form a hospitable environment, in the form of favourable financial support, tax incentives, as well as training of interested parties. On the other hand, the private sector should focus on self-promotion, creation and maintenance of the quality of the original products and services, etc. The task is to realize the opportunities and resources that exist at a destination and which are in the service of developing a new type of tourism, having in mind the target group of tourists who most often valorize this type of tourism, as well as the results achieved from creative and cultural tourism on a global level.

\section{REFERENCES}

Božić Miljković, I. (2016). Kreativne industrije u funkciji unapređenja razvoja turizma u pograničnim opštinama Jugoistočne Srbije. Ekonomski vidici 2/3, 187-198. Beograd: Društvo ekonomista Beograda.

Dupeyras, A., \& MacCallum, N. (2013). Indicators for Measuring Competitiveness in Tourism, A Guidance Document. OECD Tourism Papers. 2013/02, OECD Publishing. DOI:10.1787/5k47t9q2t923-en (accessed 07/08/2018)

Ernst \& Young Report (Dec. 2015). Cultural Times - The first global map of cultural and creative industries, pp. $8 \mathrm{https} / /$ www.ey.com/Publication/vwLUAssets/ey-cultural-times-2015/\$FILE/ey-cultural-times-2015. pdf (accessed 16/07/2018)

Gooroochurn, N., \& Sugiyarto, G. (2005). Competitiveness Indicators in Travel and Tourism Industry. Tourism Economics. 11(1), 25-43.

Jovičić, S. \& Mikić, H. (2006). Kreativne industrije u Srbiji . Belgrade: British Council, pp. 96.

Kozak, M., \& Rimmington, M. (1999). Measuring tourist destination competitiveness: conceptual considerations and empirical findings. Hospitality Management, 18: 273-283.

Krugman, P. (1997). Pop internationalism. Massachusetts: The MIT Press, pp. 6.

Melian-Gonzalez, A., \& Garcia-Falcon, J.M. (2003). Competitive potential of tourism in destinations. Annals of Tourism Research, 30(3): 720-740.

Radović, N., \& Čigoja Piper, D. (2016). Tourism as Puzzle Improvement of Creative Economy. Belgrade: SITCON 2016. Conferences Proccedings, pp. 33-36.

Sparks, E, Waits, M.J., \& Fulton, B. (2012). New Engines of Growth. Washington DC: National Governors Association.

The Economy of Culture in Europe. (Oct. 2006). Study prepared for the European Commission (DirectorateGeneral for Education and Culture). KEA European Affairs, pp. 9.

UNCTAD (2004). Declaration on Cultural Industries and Development, http://unctad.org/en/docs/tdxibpd13_ en.pdf (accessed 09/07/2018)

UNESCO (1948). Universal Declaration of Human Rights, http://www.unesco.org/education/information/50y/ nfsunesco/doc/hum-rights.html (accessed 09/07/2018.)

UNESCO (1995). Our Creative Diversity, http://unesdoc.unesco.org/images/0010/001055/105586e.pdf (accessed 09/07/2018) 
UNESCO (2001) Universal Declaration of Cultural Diversity, http://portal.unesco.org/en/ev.phpURL_ID=13179 \&URL_DO=DO_TOPIC\&URL_SECTION=201.html (accessed 09/07/2018)

UNESCO (2005). Convention on the Protection and Promotion of Cultural Expressions, https://en.unesco.org/ creativity/convention (accessed 09/07/2018)

UNESCO (2006). Towards Sustainable Strategies for Creative Tourism, http://unesdoc.unesco.org/images/0015/ 001598/159811e.pdf (accessed 25/07/2018)

UNESCO (2010). Backgrounder on Cultural Industries, http://www.unescobkk.org/fileadmin/user_upload/culture/Cultural_Industries/HK_Open_Forum/Backgrounder-FINAL.pdf (accessed 07/07/2018)

UN (2010). UN Resolution on Culture and Development, https://whc.unesco.org/document/115934 (accessed 09/07/2018)

Vlada Republike Srbije, Ministarstvo trgovine, turizma i telekomunikacija (2016). Strategija razvoja turizma Republike Srbije 2016-2025, http://mtt.gov.rs/download/3/strategija.pdf (accessed 21/08/2018)

Vukonić, B., \& Čavlek, N. (2001). Rječnik turizma. Zagreb: Masmedia.

www. ec.europa.eu/culture/keydocuments/doc/study_impact_cult_creativity_06_09.pdf (accessed 18/07/2018) www.cia.gov/library/publication/resources/the-world-factbook (accessed 19/07/2018.)

www.exitfest.org/vesti (accessed 25/07/2018)

www.kultura.gov.rs/docs/dokumenti/predlog-strategije-razvoja-kulture-republike-srbije-od-2017--do-2027-/predlog-strategije-razvoja-kulture-republike-srbije-od-2017--do-2027-.pdf (accessed 20/09/2018)

www.mtt.gov.rs (accessed 25/07/2018.)

www.srbija.gov.rs/vesti/vest.php?id=317383 (accessed 25/07/2018) 